\title{
世界植生モニタリング
}

\section{Global Monitoring of Vegetation}

\author{
本多 嘉明*, 村井 俊治* \\ 加藤喜久雄 $* *$ \\ Yoshiaki HONDA, Shunji MURAI \\ Kikuиo KATOOU
}

\begin{abstract}
The objectives are to develop a methodology fo gloabal mapping of vegetation with NOAA Global Vegetation Index and geoinformation and to monitor the globala change of bioshere.

The methodology wich has been developed by the authors is based on multi-temporal analysis in which monthly vegetation activity cycles of NVI (Normalized Vegetation Index) were recognized by pattern of vegetation types together with geoinformation such as DEM (digital elevation model).

As the result of the study, a global vegetation map with eight vegetation types which were defined by multitemporal pattern was produced using three years average of NOAA GVI for 1985 to 1987.
\end{abstract}

\section{1.はじめに}

産業革命以来, 人間活動の拡大や人口の増加は地球 の環境にとって負担となり，第 2 次大戦後は急激に大 きな負担となった。そして先進諸国で環境問題が自国 の問題として盛んに論じられるようになったのは 1960 年代後半からである。このような流れの中，1972年に は地球規模の国際会議「国連人間環境会議」(UN Conference on Human Environment）がスウェーデンの ストックホルムで国連によってはじめて開かれた。そ の約10年後, 1982年の後半から1984年にかけてアフリ カ大陸を見舞った大干ばつは約 30 万人の餓死者を出 し，当時発生していた大規模なエルニーニョとの関連 が注目された。これを契機に地球環境問題に対する世 界的な関心が高まり，地球システム科学の新しい概念 が打ち出された。まず，地球環境そのものを継続的か つ体系的に観測・監視し地球生態系の仕組みを解明す る必要が説かれた。このような中で気象衛星 NOAA

* 東京大学生産技術研究所

$* *$ 名古屋大学水圈科学研究所

「写真測量とリモートセンシング」Vol. 31，No. 1， 1992
の AVHRR センサーによる植生モニタリングは数多 く行われているが, 単なる年間累積 NVI（正規化植生 指標）や多変量解析による植生分類を行っているもの がほとんどである。これに対し本研究では「いつ葉を 出しどれくらいの期間葉を出しているか（植物の生活 活動)」すなわち植物の生活様式を類型化した生活形 (lifeuform) によって植生を分類するものである。

\section{2. 研究の目的}

本研究では，まず地球生物環境を表すものとして地 球全体の情報を提供してくれる植生をとりあげる。植 生の状態がどうあるかを把握するには植生の活動を時 系列変化でとらえる必要がある。さらに定量的に論ず るためには似た植生型の植物が生息するのに適した生 態環境および気候条件を区切るゾーニング（区分）が 必要になる。このゾーニングは著者らによって生態気 候区分 (Eco-Climate Mapping) と称され新しい概 念に基づいている。そこで, 本研究では, ゾーニング に欠かせないグローバルな植生分類の方法を提案し, 世界植生図を作成することを目的とする。 


\section{3. 使用するデータ}

本研究で使用するデー夕は世界中の植物の活動状態 を週ごとに示すグローバル植生指標 (Gloabal Vegetation Index, 以下 GVI と呼ぶ）及び世界2344地点の気 候要素をディジタルデータにした世界気象情報であ る。

GVI (グローバル植生指標)には数種類のデータがあ るが, 本研究においては GVI は1982年 4 月以降, 気象 衛星 NOAA の AVHRR 七ンサーの可視及び近赤外 バンドから求められる正規化植生指標（Normarlized Vegetation Index：以下 NVI と呼ぶ）を雲の影響を 除去するため一週間の最大值でポーラ・ステレオの座 標型にモザイク集成したもののことをいう。NVIは理 論上ー 1 から+ 1 までの值を取るが, 植生と深い関係 があるのは0.1から0.6までであり, 大きな值ほど緑色 の植生（クロロフィル）の密度が高い。現在1982年 4 月から1989年12月下旬までのデータが揃っている。
世界気象情報は日本の気象庁が世界中の 2344 力所の 地上観測点で観測された気圧, 気温, 蒸気圧, 湿度, 風速，雲量等の月毎の統計值をディジタルデータの形 にまとめたものである。現在1982年 1 月から 1989 年 1 月までのデータが揃っている。

\section{4. 植生区分の定義}

気候は地圈の地球生物環境を決定する最も重要なも ののひとつである。一般に，気候学では気候を分類す る方法として主に次の 4 つがある。

(1)気候の成因による方法

(2)気候指数または気候要素の特性や階級による方法

(3)植生による方法

(4)自然現象による方法（植生以外の自然特性を利用 したもの)

現在, 最も一般的なかつ有効な気候分類である Köppenの気候分類は(3)植生による方法を利用してい る。このことからも植生と気候ひいては地球生物環境

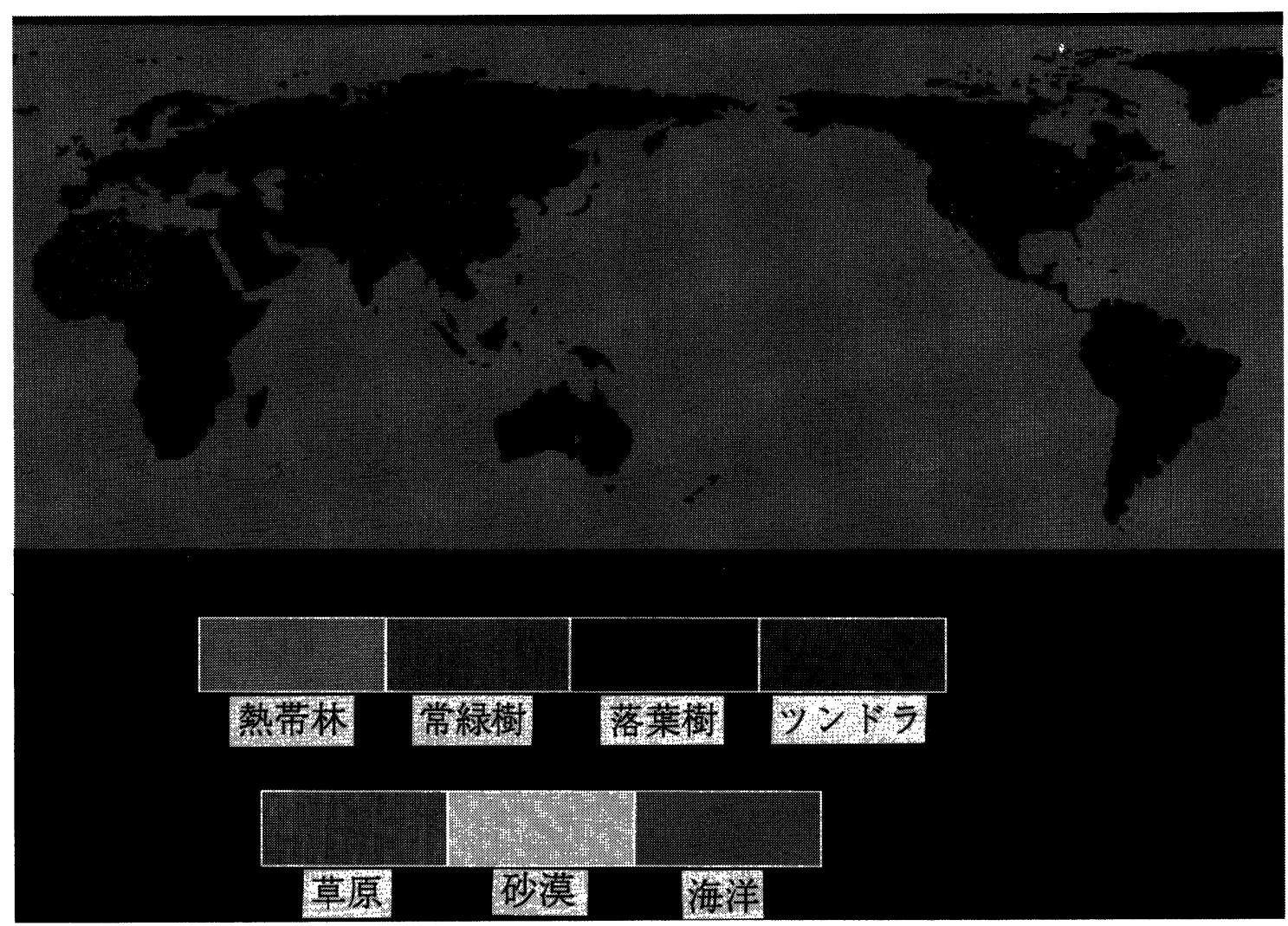

図 1 植生安定変化地点分布図 
は密接な関係を持つことが分かる。実際に植生型を分 類することを考えると，大別して次の 2 つの方法があ る。

\section{(1)種類組成を基準とする方法}

(2)優占種の生活形を基準にする方法

(1)種類組成を基準とする方法は現地の綿密な調査を 必要とし，地球全体のようなグローバルな分類をする 際には適さない。(2)優占種の生活形を基準にする方法 はグローバルな植生分布を調べるときよく用いられ， 1 年間にどのように植生の生活活動が変化するかは GVI データから知ることが出来る。さらに, 以上気象 の影響を出来る限り取り除き地球上の植生型（土地被 覆) を分類する。従来の植物学, 生態学, 地理学等で 用いられている植生区分の夕イプ分けとその定義は極 めて多く，それぞれが異なる。また，定量的な定義が ない。そこで，著者らは衛星デー夕(GVI) の NVI 月 変化のパターンから表 1 の 8 つの植生区分を定量的に 定めた。困 2 はそのパターンを示している。

\section{5. 分 類方法}

具体的な分類は次の 4 つのステップに分けて行う。 ステップ1 月間 GVI データの作成

一週間毎にある GVI デー夕を一月毎のデータに まとめる。雲の影響を取り除くためにほぼ四週間毎 の NVIの最大值をひと月のデータとする。

\section{ステップ 2 典型的な植生型の変化}

植生型によって固有の NVIの年間変動がある。 1983年から1987年までの 5 年間の月間 GVI デー夕 の中から世界気象情報の2344力所の観測点に一致し た地点の植生変化をもとめる。つぎに次式によって 求められる植生安定指数が小さいものすなわち毎年 安定した植生変化をしている地点を240地点選びだ す。選びだされた地点を図 1 に示す。それぞれの地 点がKöppenの気候分類の何に当てはまるかを気 象観測データより求める。

植生安定指数 $=\sum_{Y=1}^{5}\left(\sum_{M=1}^{12}\right.$ ( $\mathrm{Y}$ 年M月の $\mathrm{NVI}-5$ 年 間のM月の平均 $\mathrm{NVI})^{2}$ )

その後, 植生型によって決まる典型的な NVI 変 動パターンを求める。Köppen の植生を基本とした 気候分類では樹木気候を $\mathrm{A}, \mathrm{C}, \mathrm{D}$ と無樹木気候 $\mathrm{B}$, $\mathrm{E}$ の 5 種の大分類をしている。本研究では Köppen
の大分類を基本にして植物の生活形によって樹木気 候を熱带林, 常緑樹, 落葉樹, 無樹木気候をツンド ラ, 草原, 半砂漠, 砂漠に分けた。したがってパター ンは熱帯林, 常緑樹, 落葉樹, ツンドラ, 草原, 半 砂漠, (ほぼ無植生), 砂漠 (無植生) の 7 つがあり,

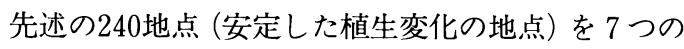
パターンに分ける。図 2 にあるうに 7 パターン毎 に 5 年間 (1983年〜1987年)の月毎平均 NVI を求め 典型的な NVI 変動パターンを作成する。

スッテプ 3 各年のグローバルな植生型分類

1983年から1987年までの 5 力年の月間 GVI デー 夕に対し，ピクセル毎に NVI 変動パターンを調べ, 植生型の分類を行う。植生分類はピクセル毎の NVI 年間変動パターンの NVIのピークを用いて基準化 を行いステップ 2 で求めた典型的な植生変化パター ンとの距離を求める。距離は NVI 值を 1 月から 12 月までの12次元空間に置いたときのユークリッド距 離であり, 基準化の意味は北半球と南半球による植 生変化パターンのずれを補正するためである。それ ぞれのピクセルは最も距離の近い植生パターンに分 類される。さらに, 砂漠と判定された地域のうち標 高が $3000 \mathrm{~m}$ 以上のために植生がないと考えられる 地域を高山性砂漠として別に分類した。

\section{ステップ 4 異常気象の影響除去}

異常気象のように気象条件が悪いときには本来の NVI 年間変動, パターンを取らない地域が出来てく る。土地被覆を分類するという意味において森林で あるところが NVI 年間変動パ夕ーンが正常でない からといって森林と分類されないのは土地被覆分類 の点で良くない。そこで，世界気象情報を用いて異 常気象を示している観測点が多い1983年1984年を除 き, 後の1985年, 1986年, 1987年の 3 年間の GVI デー 夕を用い 3 年間の月別平均 GVI デー夕を作成する。 この平均 GVI デー夕を用いて植生分布図を作成す る。

ところで, 異常気象とは気象庁の「異常気象レポー ト84」によれば次の 2 つの場合と定義されている。

(1) それぞれの地点で月平均気温や月降水量が過去 30 年間あるいはそれ以上にわたって観測されな かったほど平年值から偏った場合

(2) 月平均気温が正規分布する場合は，平年值から の偏差値が標準偏差値の 2 倍以上偏った場合 入手可能な平年值の情報は1931年から1960年のもの 
表 1 植生区分の定義

\begin{tabular}{|c|c|}
\hline 植生区分 & 定 \\
\hline 熱帯林 & パターンは年間を通じてＮＶＩがおよそ０．3前後でほぼ一定である。 \\
\hline 常緑樹 & $\begin{array}{l}\text { 常緑樹はほぼ熱帯林と同じパターンを示すが、冬季にN V I の值がやや下がり平たい丘 } \\
\text { の形に似ている。 }\end{array}$ \\
\hline 落葉樹 & ピークが約 0.4 と高い N V I の一山を示している。 \\
\hline ツンドラ & N V I の変化パターンは非常に鋭いピークを持っている。 \\
\hline 草原 & $\begin{array}{l}\text { N V I のピークが0．２程度である。しかし、草原の N V I 変化パターンはピークが } 1 \\
\text { つのもの } 2 \text { つのの余りはっきりしないむのと単純ではない。 }\end{array}$ \\
\hline 半砂漠 & 一年を通じてＮＶＩが低いが、短期間だけＮＶＩが少しだけ上がる。 \\
\hline 砂漠 & N V I が--年を通じてきわめて低いところで一定である。 \\
\hline 高山生砂漠 & 標高が３０００ｍ以上でN V I が一年を通じてきわめて低いところで一定である。 \\
\hline
\end{tabular}

NVI

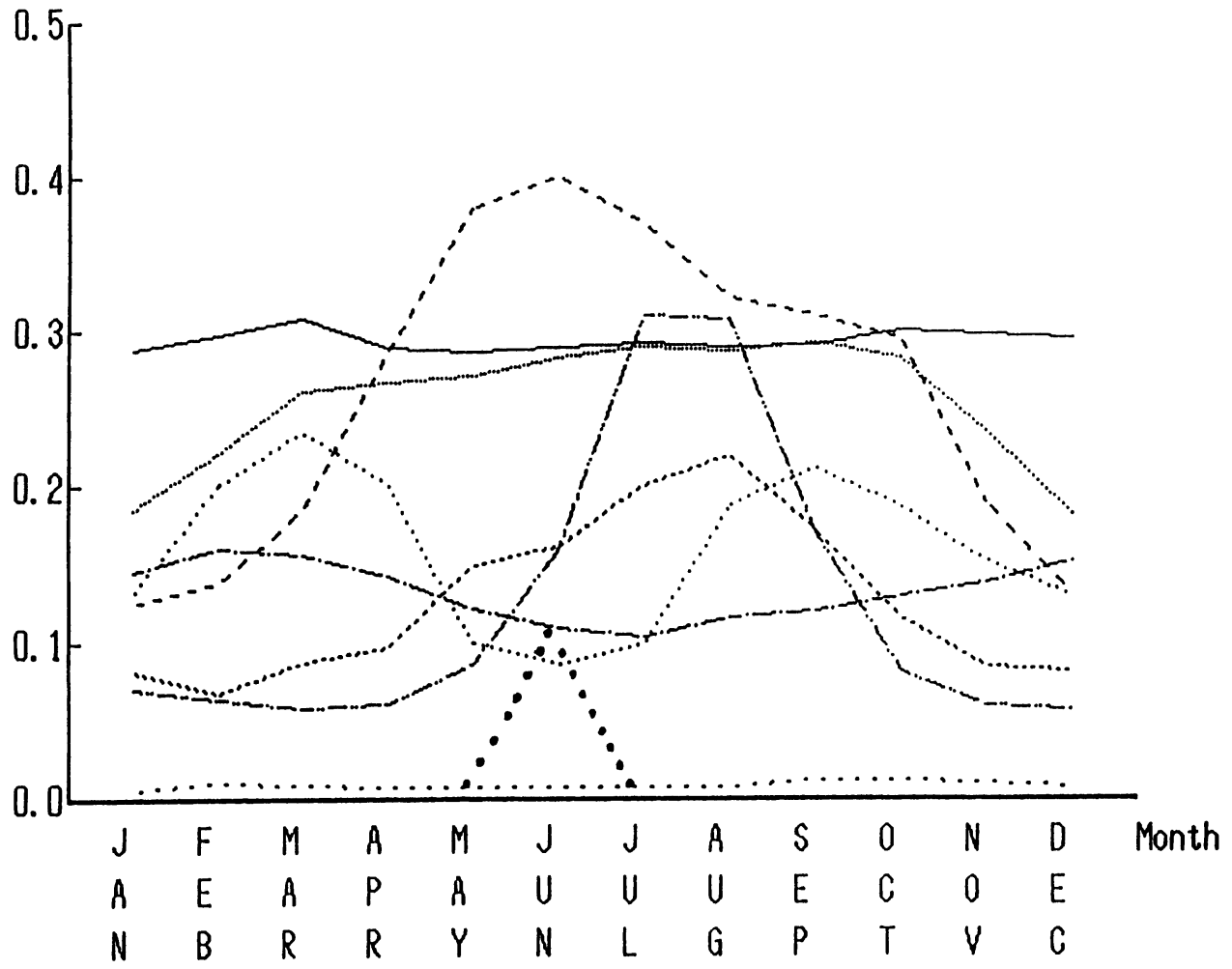

熟带林

常椂樹林

落葉樹林

-・- ッンドラ

…. 草原

- - 草原

草原

半 砂 漠

砂漠

高山性秒谟

図 2 植生区分と植生季節変動パターン 
表 2 - 1 1983年世界植生面積表

\begin{tabular}{|c|c|c|c|c|c|c|c|c|c|}
\hline & 帯林 & 緑樹 & 落葉樹 & ッン゙ラ & 草 原 & 半砂漠 & 高山悎 & 砂 漠 & 合 計 \\
\hline 欧 洲 & & 2 & & $\begin{array}{r}2293 . \\
4.15\end{array}$ & $\begin{array}{r}24212 . \\
43.84\end{array}$ & & $\begin{array}{r}1502 . \\
2.72\end{array}$ & $\begin{array}{l}8153 . \\
14.76\end{array}$ & 55226. \\
\hline $\begin{array}{r}\text { オセア } \\
\text { 三ア }\end{array}$ & 83 & $\begin{array}{r}937 . \\
11.01\end{array}$ & & 0.00 & $\begin{array}{l}2337 . \\
27.47\end{array}$ & & 0.01 & $\begin{array}{l}790 . \\
9.28\end{array}$ & 3507. \\
\hline 北 米 & $\begin{array}{l}358 . \\
1.48 \\
\end{array}$ & $\begin{array}{r}1261 . \\
5.20 \\
\end{array}$ & & $\begin{array}{l}356 . \\
1.47 \\
\end{array}$ & $\begin{array}{r}10688 \\
44.07 \\
\end{array}$ & & $\begin{array}{l}10 . \\
0.04\end{array}$ & $\begin{array}{l}937 . \\
3.87\end{array}$ & 24253. \\
\hline 南 米 & $\begin{array}{l}2502 . \\
14.48\end{array}$ & & & 0.00 & $\begin{array}{l}3499 \\
20.25\end{array}$ & $\begin{array}{r}1053 . \\
6.10\end{array}$ & $\begin{array}{l}308 . \\
1.79\end{array}$ & $\begin{array}{l}700 \\
4.05\end{array}$ & 17274. \\
\hline アフ & $\begin{array}{l}195 . \\
0.67 \\
\end{array}$ & $\begin{array}{r}2589 \\
8.87 \\
\end{array}$ & $\begin{array}{l}4016 \\
13.75 \\
\end{array}$ & 0.00 & $\begin{array}{l}8346 . \\
28.58\end{array}$ & & 0.0. & $\begin{array}{r}10742 . \\
36.78\end{array}$ & 29204. \\
\hline 合 計 & $\begin{array}{r}3890 . \\
2.89\end{array}$ & $\begin{array}{l}3953 . \\
10.38\end{array}$ & $\begin{array}{l}8181 \\
13.52\end{array}$ & $\begin{array}{l}2649 . \\
1.97\end{array}$ & $\begin{array}{r}49082 . \\
36.50\end{array}$ & $\begin{array}{r}23563 . \\
17.52\end{array}$ & $\begin{array}{r}1824 . \\
1.36\end{array}$ & $\begin{array}{r}21323 . \\
15.86\end{array}$ & 134465. \\
\hline
\end{tabular}

上段：×1000平方キロメートル 下段：パーセント

表 2 - 2 1984年世界植生面積表

\begin{tabular}{|c|c|c|c|c|c|c|c|c|c|}
\hline & 熱帯林 & 常緑樹 & 落葉樹 & ツン゙ラ & 草 原 & 半砂漠 & 膏山性 & 砂 漠 & 合 計 \\
\hline 原涂 & $\begin{array}{l}191 . \\
0.35\end{array}$ & $\begin{array}{r}1945 . \\
3.52 \\
\end{array}$ & $\begin{array}{l}9096 . \\
16.47\end{array}$ & $\begin{array}{r}2641 . \\
4.78 \\
\end{array}$ & \begin{tabular}{|r|}
23065 \\
41.76 \\
\end{tabular} & $\begin{array}{l}7939 . \\
14.38 \\
\end{array}$ & $\begin{array}{r}1335 \\
2.42 \\
\end{array}$ & $\begin{array}{l}9014 . \\
16.32\end{array}$ & 55226. \\
\hline オセア & $\begin{array}{l}17 . \\
0.20\end{array}$ & $\begin{array}{l}555 . \\
6.52 \\
\end{array}$ & $\begin{array}{l}286 . \\
3.36 \\
\end{array}$ & 0.00 & $\begin{array}{l}3114 . \\
36.60\end{array}$ & $\begin{array}{l}4052 . \\
47.63\end{array}$ & 0.02 & $\begin{array}{l}482 . \\
5.67\end{array}$ & 8507. \\
\hline 北 米 & $\begin{array}{l}110 . \\
0.45 \\
\end{array}$ & $\begin{array}{l}830 . \\
3.42 \\
\end{array}$ & $\begin{array}{l}5727 . \\
23.61 \\
\end{array}$ & $\begin{array}{l}530 . \\
2.19 \\
\end{array}$ & $\begin{array}{r}10725 \\
44.22 \\
\end{array}$ & $\begin{array}{l}4347 . \\
17.93 \\
\end{array}$ & $\begin{array}{r}7.5 \\
0.03 \\
\end{array}$ & $\begin{array}{r}1975 . \\
8.14\end{array}$ & 24253. \\
\hline 南 米 & $\begin{array}{l}668 . \\
3.86 \\
\end{array}$ & $\begin{array}{l}7222 . \\
41.81\end{array}$ & $\begin{array}{l}1786 . \\
10.34\end{array}$ & 0.00 & $\begin{array}{l}5255 . \\
30.42 \\
\end{array}$ & $\begin{array}{r}1333 . \\
7.72 \\
\end{array}$ & $\begin{array}{l}332 . \\
1.92\end{array}$ & $\begin{array}{l}679 . \\
3.93 \\
\end{array}$ & 17274. \\
\hline アフ リカ & $\begin{array}{l}15 \\
0.05 \\
\end{array}$ & $\begin{array}{r}1568 . \\
5.37\end{array}$ & $\begin{array}{r}2605 \\
8.92\end{array}$ & 0.00 & $\begin{array}{l}9948 . \\
34.06\end{array}$ & $\begin{array}{l}3482 . \\
11.92\end{array}$ & 0.3 .01 & $\begin{array}{r}11583 . \\
39.66\end{array}$ & 29204. \\
\hline 合 計 & $\begin{array}{r}1001 \\
0.74\end{array}$ & $\begin{array}{r}12119 . \\
9.01\end{array}$ & $\begin{array}{r}19499 \\
14.50\end{array}$ & $\begin{array}{r}3171 . \\
2.36\end{array}$ & $\begin{array}{r}52107 . \\
38.75\end{array}$ & $\begin{array}{r}21154 . \\
15.73\end{array}$ & $\begin{array}{r}1679 . \\
1.25\end{array}$ & $\begin{array}{r}23734 . \\
17.65\end{array}$ & 134465 \\
\hline
\end{tabular}

上段：×1000 平方キロメートル 下段：パーセント

表 $2-3$ 1985年世界植生面積表

\begin{tabular}{|c|c|c|c|c|c|c|c|c|c|}
\hline & 帯林 & 常緑樹 & 落葉樹 & ツン゙ラ & 草 原 & 半砂漠 & 高山性 & 砂 漠 & 合 計 \\
\hline 原 洲 & 1.98 & 3.56 & 21.74 & $\begin{array}{r}3300 \\
5.97 \\
\end{array}$ & $\begin{array}{r}19684 . \\
35.64 \\
\end{array}$ & & $\begin{array}{r}1351 . \\
2.45\end{array}$ & $\begin{array}{l}8350 . \\
15.12\end{array}$ & 522 \\
\hline $\begin{array}{c}\text { オセア } \\
\text { =? }\end{array}$ & $\dot{9}$ & $\begin{array}{r}879 . \\
10.33 \\
\end{array}$ & 8 & $\begin{array}{r}0.00 \\
0.00\end{array}$ & $\begin{array}{l}1824 . \\
21.45 \\
\end{array}$ & & 0.00 & $\begin{array}{l}1032 . \\
12.13\end{array}$ & 8507. \\
\hline 北 米 & 4 & $\begin{array}{r}1409 . \\
5.81 \\
\end{array}$ & & $\begin{array}{l}628 . \\
2.59 \\
\end{array}$ & & & 0.9 .94 & $\begin{array}{l}1865 . \\
7.69\end{array}$ & 3. \\
\hline 南 米 & $\begin{array}{l}5841 \\
33.81\end{array}$ & 297. & $\begin{array}{c}169 \\
9 .\end{array}$ & $0.0 \dot{0}$ & $\begin{array}{l}2371 \\
13.73\end{array}$ & $\begin{array}{l}1033 . \\
5.98\end{array}$ & $\begin{array}{l}313 . \\
1.81\end{array}$ & $\begin{array}{l}728 . \\
4.22\end{array}$ & 17274. \\
\hline アフォカ & 91 & $\begin{array}{l}3542 . \\
12.13\end{array}$ & $\begin{array}{l}4291 . \\
14.69\end{array}$ & 0.00 & $\begin{array}{l}7406 . \\
25.36\end{array}$ & $\begin{array}{l}3229 . \\
11.06\end{array}$ & $0.3^{3 .} \mathrm{i}$ & $\begin{array}{r}10176 \\
34.84\end{array}$ & 204. \\
\hline 合 計 & $\begin{array}{r}8341 . \\
6.20\end{array}$ & $\begin{array}{r}13091 . \\
9.74\end{array}$ & $\begin{array}{r}24464 . \\
18.19\end{array}$ & $\begin{array}{l}3928 . \\
2.92\end{array}$ & $\begin{array}{l}40842 \\
30.37\end{array}$ & $\begin{array}{r}19971 . \\
14.85\end{array}$ & $\begin{array}{r}1676 . \\
1.25\end{array}$ & $\begin{array}{r}22151 . \\
16.47\end{array}$ & 134465. \\
\hline
\end{tabular}

上段：×1000 平方キロメートル 下段：パーセント 
表 $2-4$ 1986年世界植生面積表

\begin{tabular}{|c|c|c|c|c|c|c|c|c|c|}
\hline & 熱帯林 & 常緑樹 & 落葉樹 & ツン & 草 原 & 半砂漠 & 高山怢 & 砂 漠 & 合 計 \\
\hline $\begin{array}{l}\text { ア } シ ゙ ア ~ \\
\text { 欧 } \\
\end{array}$ & $\begin{array}{r}1435 \\
2.60 \\
\end{array}$ & 4.26 & $\begin{array}{r}11772 . \\
21.32 \\
\end{array}$ & $\begin{array}{r}2727 . \\
4.94 \\
\end{array}$ & $\begin{array}{r}19813 . \\
35.88 \\
\end{array}$ & $\begin{array}{l}7214 . \\
13.06 \\
\end{array}$ & $\begin{array}{r}1219 \\
2.21 \\
\end{array}$ & $\begin{array}{l}8691 . \\
15.74 \\
\end{array}$ & 55226. \\
\hline オセア & $\begin{array}{l}348 . \\
4.09\end{array}$ & $\begin{array}{l}836 \\
9.83\end{array}$ & $\begin{array}{l}436 . \\
5.13\end{array}$ & 0.00 & $\begin{array}{l}1635 \\
19.22\end{array}$ & $\begin{array}{l}4383 \\
51.52\end{array}$ & 0.00 & $\begin{array}{r}869 \\
10.2 \mathrm{i}\end{array}$ & 8507. \\
\hline 北 米 & $\begin{array}{l}504 . \\
2.08\end{array}$ & $\begin{array}{r}1499 . \\
6.18\end{array}$ & $\begin{array}{l}6035 . \\
24.88\end{array}$ & $\begin{array}{l}537 . \\
2.21 \\
\end{array}$ & $\begin{array}{l}9876 \\
40.72\end{array}$ & $\begin{array}{l}4044 . \\
16.67\end{array}$ & 0.0 .62 & $\begin{array}{r}1753 . \\
7.23\end{array}$ & 24253. \\
\hline 南 米 & $\begin{array}{l}5983 . \\
34.63\end{array}$ & $\begin{array}{l}4993 . \\
28.90\end{array}$ & $\begin{array}{r}1565 . \\
9.06\end{array}$ & 0.00 & $\begin{array}{l}2613 . \\
15.13\end{array}$ & $\begin{array}{r}1039 \\
6.02 \\
\end{array}$ & $\begin{array}{l}281 . \\
1.63 \\
\end{array}$ & $\begin{array}{l}801 \\
4.63 \\
\end{array}$ & 17274. \\
\hline アプ & $\begin{array}{l}676 . \\
2.31\end{array}$ & $\begin{array}{l}3579 . \\
12.25\end{array}$ & $\begin{array}{l}4297 . \\
14.71\end{array}$ & 0.00 & $\begin{array}{l}7286 . \\
24.95\end{array}$ & $\begin{array}{l}3033 \\
10.38\end{array}$ & 0.01 & $\begin{array}{r}10331 . \\
35.37\end{array}$ & 29204. \\
\hline 合 計 & $\begin{array}{r}8946 . \\
6.65\end{array}$ & $\begin{array}{r}13261 . \\
9.86\end{array}$ & $\begin{array}{r}24105 . \\
17.93\end{array}$ & $\begin{array}{r}3264 . \\
2.43\end{array}$ & $\begin{array}{r}41223 . \\
30.66\end{array}$ & $\begin{array}{r}19712 . \\
14.66\end{array}$ & $\begin{array}{r}1509 . \\
1.12\end{array}$ & $\begin{array}{r}22444 \\
16.69\end{array}$ & 134465. \\
\hline
\end{tabular}

上段：×1 10000 平方キロメートル 下段：パーセント

表 2 - 5 1987年世界植生面積表

\begin{tabular}{|c|c|c|c|c|c|c|c|c|c|}
\hline & 熱帯林 & 常緑樹 & 落葉樹 & ツン゙ & 草 原 & 半砂漠 & 高山情 & 砂 漠 & 合 計 \\
\hline 茨ジア 州 & $\begin{array}{r}1273 . \\
2.31\end{array}$ & $\begin{array}{r}2623 \\
4.75\end{array}$ & $\begin{array}{r}11139 . \\
20.17\end{array}$ & $\begin{array}{r}3438 . \\
6.23\end{array}$ & $\begin{array}{r}20956 . \\
37.94\end{array}$ & 12.23 & $\begin{array}{r}1127 . \\
2.04\end{array}$ & $\begin{array}{l}7915 . \\
14.33\end{array}$ & 55226. \\
\hline オセア & $\begin{array}{l}326 \\
3.83\end{array}$ & $\begin{array}{l}4 . \\
92\end{array}$ & $\begin{array}{l}294 . \\
3.45\end{array}$ & 0.00 & $\begin{array}{l}2094 . \\
24.61\end{array}$ & $\begin{array}{l}4494 . \\
52.83\end{array}$ & 0.00 & $\begin{array}{l}455 \\
5.35 \\
\end{array}$ & 8507. \\
\hline 北 米 & $\begin{array}{l}462 . \\
1.90\end{array}$ & $\begin{array}{r}1569 \\
6.47\end{array}$ & $\begin{array}{l}6111 . \\
25.20\end{array}$ & $\begin{array}{l}862 . \\
3.55\end{array}$ & $\begin{array}{l}9997 . \\
41.22\end{array}$ & $\begin{array}{l}4139 . \\
17.06\end{array}$ & 0.02 & $\begin{array}{r}1110 . \\
4.57\end{array}$ & 24253. \\
\hline 南 米 & $\begin{array}{l}4177 . \\
24.18\end{array}$ & $\begin{array}{l}6165 . \\
35.69\end{array}$ & $\begin{array}{l}1923 . \\
11.13\end{array}$ & 0.00 & $\begin{array}{l}2890 . \\
16.73\end{array}$ & $\begin{array}{r}1293 . \\
7.48\end{array}$ & $\begin{array}{l}242 . \\
1.40\end{array}$ & $\begin{array}{l}584 . \\
3.38\end{array}$ & 17274. \\
\hline アプカ & $\begin{array}{l}416 . \\
1.42\end{array}$ & $\begin{array}{l}3262 . \\
11.17\end{array}$ & $\begin{array}{l}4529 \\
15.51\end{array}$ & 0.00 & $\begin{array}{l}7247 \\
24.82\end{array}$ & $\begin{array}{l}3561 . \\
12.19\end{array}$ & 3.01 & $\begin{array}{r}10185 . \\
34.88\end{array}$ & 29204. \\
\hline 合 計 & $\begin{array}{r}6654 . \\
4.95\end{array}$ & $\begin{array}{r}14463 . \\
10.76\end{array}$ & $\begin{array}{r}23997 \\
17.85\end{array}$ & $\begin{array}{r}4300 \\
3.20\end{array}$ & $\begin{array}{r}43184 . \\
32.12\end{array}$ & $\begin{array}{r}20243 . \\
15.05\end{array}$ & $\begin{array}{r}1375 . \\
1.02\end{array}$ & $\begin{array}{r}20249 . \\
15.06\end{array}$ & 134465. \\
\hline
\end{tabular}

上段：×1000 平方キロメートル 下段：パーセント

表 2-6 世界植生面積表（1985年から1987年までの平均值）

\begin{tabular}{|c|c|c|c|c|c|c|c|c|c|}
\hline & 帯林 & 常緑樹 & 落葉樹 & ツン゙ & 草 原 & 半砂漠 & 高山性 & 砂 漠 & 合 計 \\
\hline 原济 & 2.30 & $\begin{array}{l}4 . \\
19\end{array}$ & 21 & $\begin{array}{r}3155 \\
5.71 \\
\end{array}$ & $\begin{array}{r}20151 . \\
36.49\end{array}$ & 2. 94 & $\begin{array}{r}1232 . \\
2.23\end{array}$ & $\begin{array}{l}8319 . \\
15.06\end{array}$ & 55226 . \\
\hline オセア & $\begin{array}{l}349 . \\
4.10\end{array}$ & $\begin{array}{r}853 . \\
10.03\end{array}$ & $\begin{array}{l}384 . \\
4.52\end{array}$ & 0.00 & & & 0.00 & $\begin{array}{l}785 \\
9.23\end{array}$ & 8507. \\
\hline 北 米 & $\begin{array}{l}480 . \\
1.98\end{array}$ & $\begin{array}{r}1492 . \\
6.15\end{array}$ & $\begin{array}{l}6066 . \\
25.01\end{array}$ & $\begin{array}{l}676 . \\
2.78\end{array}$ & $\begin{array}{l}9810 . \\
40.45\end{array}$ & $\begin{array}{l}4147 . \\
17.10\end{array}$ & 0.03 & $\begin{array}{r}1576 . \\
6.50\end{array}$ & 24253. \\
\hline 南 米 & $\begin{array}{l}5334 . \\
30.87\end{array}$ & $\begin{array}{l}5485 \\
31.75\end{array}$ & 9.99 & 0.00 & $\begin{array}{l}2625 . \\
15.20\end{array}$ & $\begin{array}{r}1122 . \\
6.49\end{array}$ & $\begin{array}{l}279 \\
1.61\end{array}$ & $\begin{array}{l}704 \\
4.08\end{array}$ & 17274 . \\
\hline アフ & $\begin{array}{l}50 . \\
.88 \\
\end{array}$ & $\begin{array}{l}3461 . \\
11.85 \\
\end{array}$ & $\begin{array}{l}4372 . \\
14.97 \\
\end{array}$ & 0.00 & $\begin{array}{l}7313 . \\
25.04 \\
\end{array}$ & $\begin{array}{l}3274 . \\
11.21 \\
\end{array}$ & 0.31 & $\begin{array}{c}10231 . \\
35.03 \\
\end{array}$ & 29204. \\
\hline 合 計 & $\begin{array}{r}7981 . \\
5.94\end{array}$ & $\begin{array}{r}13605 \\
10.12\end{array}$ & $\begin{array}{r}24188 . \\
17.99\end{array}$ & $\begin{array}{r}3831 . \\
2.85\end{array}$ & $\begin{array}{r}41750 . \\
31.05\end{array}$ & $\begin{array}{r}19976 . \\
14.86\end{array}$ & $\begin{array}{r}1520 . \\
1.13\end{array}$ & $\begin{array}{c}21615 \\
16.07\end{array}$ & 34465 . \\
\hline
\end{tabular}

上段：×1000 平方キロメートル 下段：パーセント 


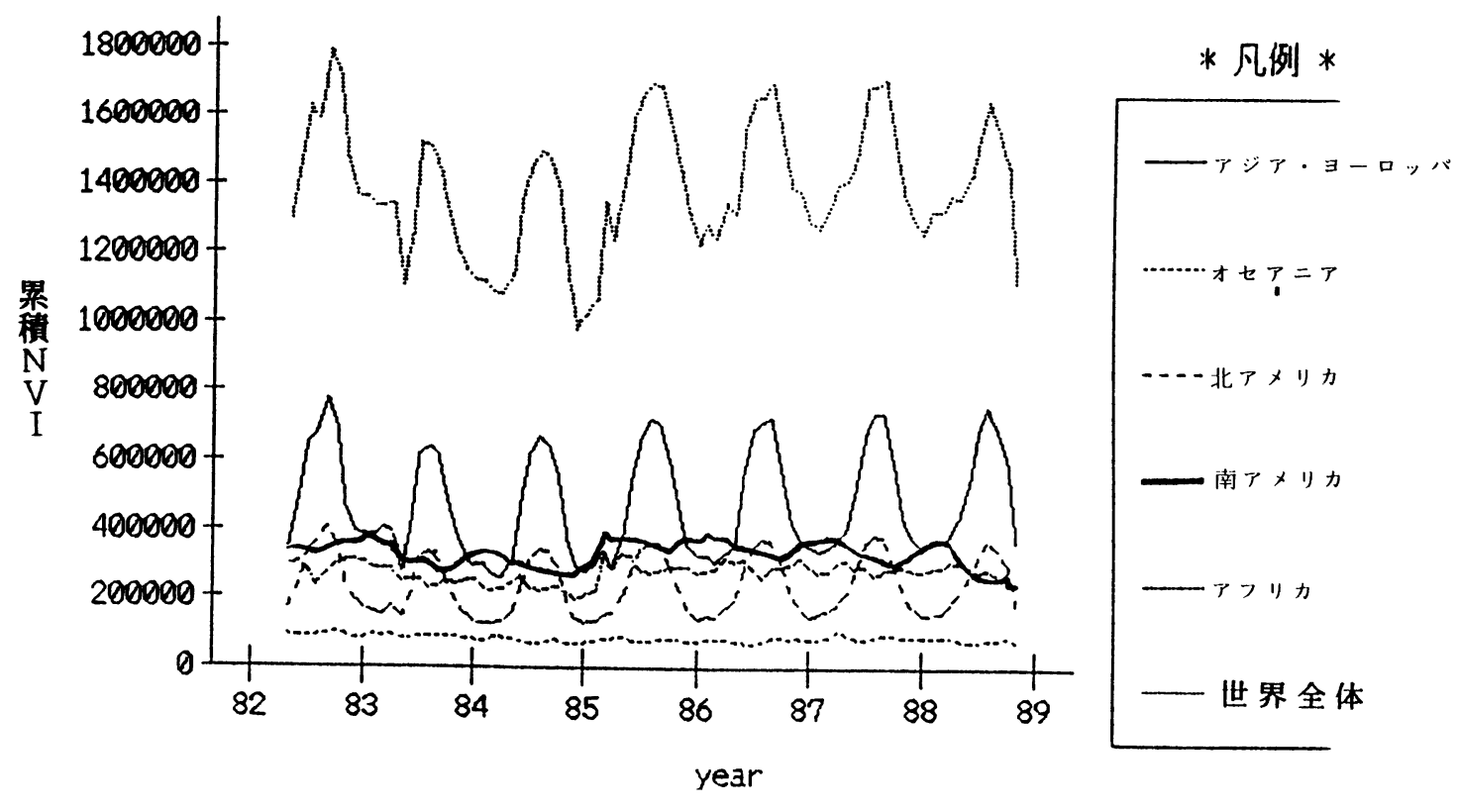

図4 累積 NVI

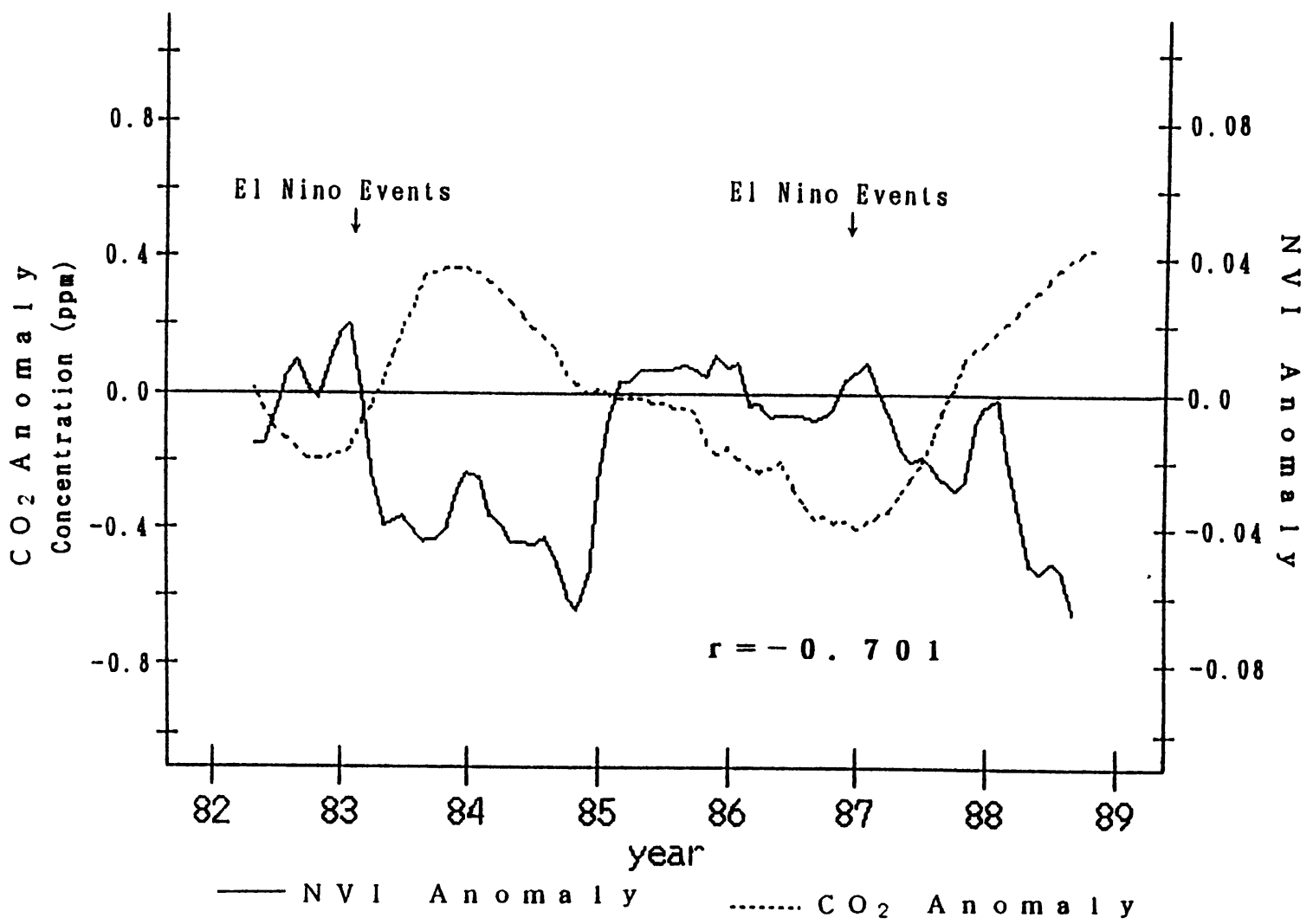

図 $5 \mathrm{Co}_{2}$ 異常值とアマゾンの植生活動 
であり，最高值と最少值が記録されている。したがっ て，異常気象かそうでないかの判断はの場合に当ては まるかそうでないかによって行った。図 3 は上記の方 法で分類した1983年から1987年までの世界植生図およ び1985年から1987年の 3 年間の平均から作成した世界 植生図である。

\section{6.世界植生図が語ること}

本研究で得られた世界植生分布の結果を表 2 によっ て示す。これらの表から1983年および1984年の結果と その他の年の結果を比較すると，1983年および1984年 の熱帯林と判定された地域がその他の年よりかなり小 さいことが解る。これは, 本研究の新しい植生分類が 植物の生活活動を NVIの変化パターンでとらえ，そ のパターンに基づいて分類を行っているためである。 すなわち，1983年および1984年は異常気象のため熱帯 地域に本来そこの植生が行う健全な生活活動をしな かった地域が多くあることを示している。

異常気象の影響をできるだけ取り除いた1985年から 1987 年の 3 年間の平均から作成した植生分布に注目す ると, 全世界で森林（熱帯林・常緑樹・落葉樹）は約 $34 \%$, 草原 (ツンドラ・草原) は約 $33 \%$, 砂漠（半砂 漠・高山性砂漠・砂漠）は約 $33 \%$ とそれぞれ 3 分の 1 づつと極めて興味深い結果が得られた。

この結果は1983年から1986年に国連の FAO がまと めた統計結果（森林：約 $31.2 \%$, 草原：約 $35.4 \%$, 砂 漠：約 $33.4 \%)$ をほとんど同じである。

本研究で定義した植生区分は本来の植物学とは異な ク，先に述べたような年間の NVI の変化パターンに よって定義されたものである。砂漠と分類された地域 の中には1年を通して雪水に覆われた部分も含まれて いる。

\section{7. 大気中の $\mathrm{CO}_{2}$ 濃度と植生活動}

エルニーニョ現象がおきると大気中 $\mathrm{CO}_{2}$ 濃度が高 くなるが，原因が明らかにされていなかった。図 3 と 表 2 にあるように地球全体での植生の活動が年によっ てかなり変わっていることが解る。全世界の NVIを 合計した值，累加 NVI をグラフにすると図 4 になる。 図 4 から1983年と1984年の累加 NVI が他の 3 年に比 べて極端に小さく，今世紀最大のエルニーニョ現象が
発生した83年・84年の両年の植生の活動が極端に低 かったことが解る。そこで南極と八ワイのマウナロア で観測された大気中 $\mathrm{CO}_{2}$ 濃度の平均值と両観測点に 最も近い熱带地域であるアマゾン全域の植生活動を比 較した。図 5 は観測された $\mathrm{CO}_{2}$ 濃度からトレンドとし て増加する分と季節変動分を取り除いた $\mathrm{CO}_{2}$ 濃度の 異常值とアマゾン全域の植生が示す NVI の平均值か ら季節変動分を取り除いた值をしめしている。両者の 関係は図 5 のように高い逆相関 $(\mathrm{R}=-0.701)$ 示すこ とが解り, 陸域の植生活動が大気中の $\mathrm{CO}_{2}$ 濃度と密接 な関係があるといえる。

\section{8.まと め}

以上を明らかになったことをまとめる。

(1) NOAA グローバル植生指標 (GVI, Global Vegetation Index）デー夕を用いた定量的植生分類の定 義として「植生季節変動パターンによる植生分類法」 を提案することができた。

（2）1983年から1987年までの植生図と地域ごとに植生 夕イプ別の面積を求めた。また, 本研究の定義に従っ た植生困は更新が容易にできることも 5 年間の植生 困作成から証明できた。

（3） 1982年 4 月から1988年10月まで植生指標の変動と 気候の変動との関連が明らかにになった。特に，ア マゾンの熱帯林の活動とエルニーニョ現象・ $\mathrm{CO}_{2}$ 濃 度との関連を示すデータが世界ではじめて得られ た。

\section{9. 今後の発展}

今まで世界にどれだけの面積の森林や砂漠があるの か信頼性のある定量的統計がなかった。また，その定 義もあいまいであった。本研究により定義が定量的に 明らかにされ，面積と分布が求められたことは意義が 大きい。しかし，次に述べるいくつかの問題点が残さ れている。

1）ツンドラなど高緯度地域では冬季に太陽高度が低 くなり，地表面の観測が十分なされているとは考之 られない。この解決のため, 人工衛星から得られた データ以外にも植物の生息限界などの情報を加味す る必要がある。植生の生態学的限界値の情報を蓄積 し，地上で得られた観測值とともに分類に応用する 
必要がある。

2) GVII データは $20 \mathrm{~km}$ と粗いが, 現在 $4 \mathrm{~km}$ あるい は $1 \mathrm{~km}$ の分解能のデー夕整備が行われおり, さら に精度を高める必要がある。

\section{参 考 文 献}

1) 吉岡邦二：植物地理学, 共立出版, 昭和 48 年 6 月 30 日

2) 吉野正敏: 気候学, 大明堂, 昭和53年 5 月 27 日

3 ）奈須紀幸: 大気と海洋, 日本放送出版協会, 昭和 61 年 3 月 20 日

4 ）岩城英夫：生態学概論, 日本放送出版協会, 昭和 61 年 3 月 20 日

5 ) 本多嘉明, 村井俊治 : GLOBAL VAEGETATION INDEX を用いた植生図について：日本写真測量学会 年次学術講演会発表論文集 pp135 138：1989年10月

6 ) Yoshiaki Honda, Shunji Murai : Vegetation Mapping Using Global Vegetation Index and Weataher Data: 10th ACRS, Kuala Lumpurs, Malaysia, ppA $-2-4-1 \sim \mathrm{A}-2-4-6: 1989$ 年11月

7 ）村井俊治, 本多嘉明：衛星による地球生物環境の変動 解明: 文部省科学研究費 重点領域研究「衛星による地 球環境の解明」pp65 70：1990年 2 月
8 ）加藤喜久雄, 本多嘉明, 村井俊治：エルニーニョ・熱带 雨林生産 - 大気 $\mathrm{CO}_{2}$ 濃度の関連性について：日本海洋学 会, 1990年

9) Yoshiaki Honda, Shunji Murai : Vegetation Mapping Using Global Vegetation Index : ISPRS Commission IV Tsukuba Japan pp608 615：1990年 5 月

10) Shunji Murai, Yoshiaki Honda : Eco-Climate Map : ISPRS Commission I Manaus Brazil：1990年 6 月

11) Shunji Murai, Yoshiaki Honda: Vegetation Mapping Using Global Vegetation Index : V International Congress of Ecology 1990 S2-3-04〔14〕：1990年 8 月

12) Shunji Murai, Yoshiaki Honda: Global Change Monitoring of Biosphere using NOAA Vegetation Index Geo-information: The National Biological Conference of Thailand including Asia and the Pacific Regions : Global Change : Effects on Tropical Forest, Agricaltural, Urban and Industrial Ecosystems : 1990 年10月 


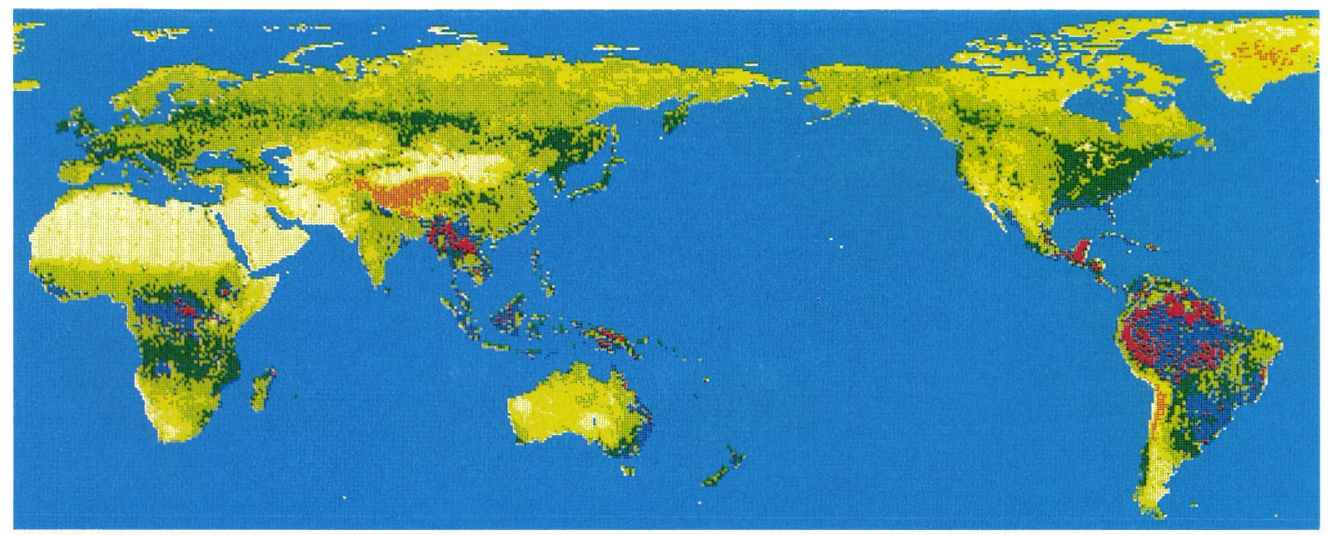

図 3 - 1 1983年 世界植生図

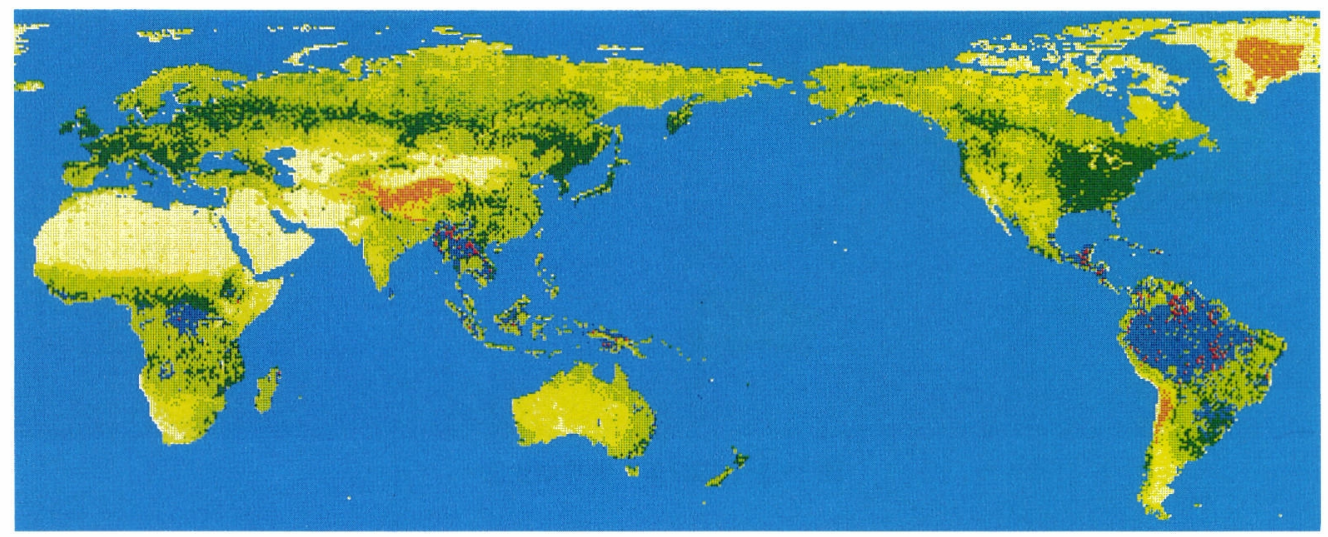

目 3 - 2 1984年 世界植生図

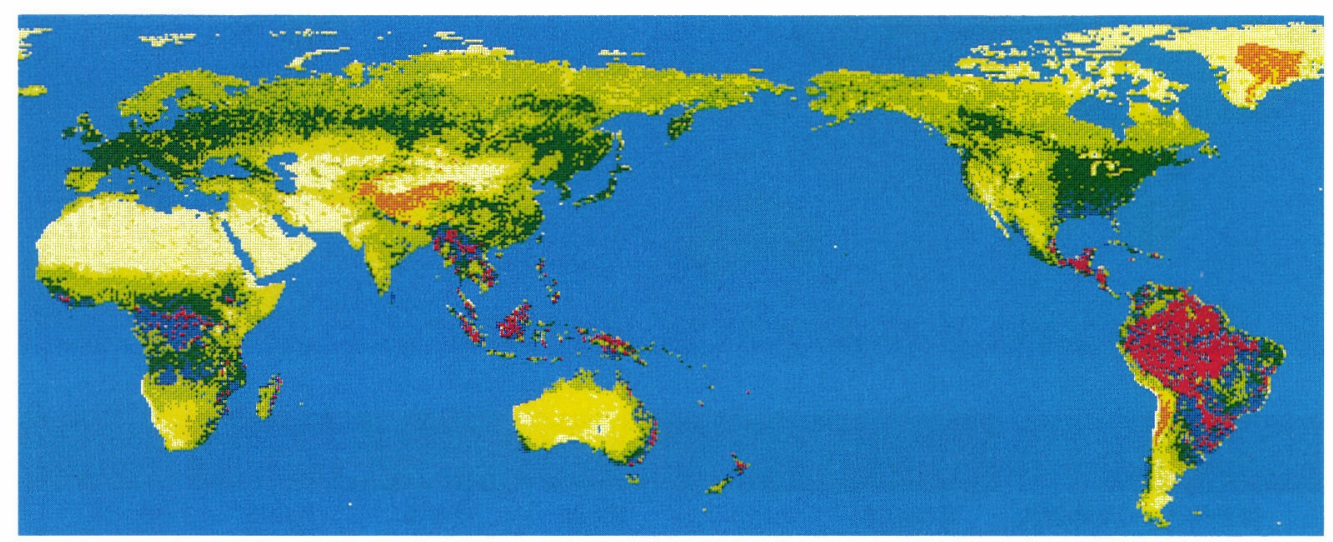

図3-3 1985年 世界植生図 


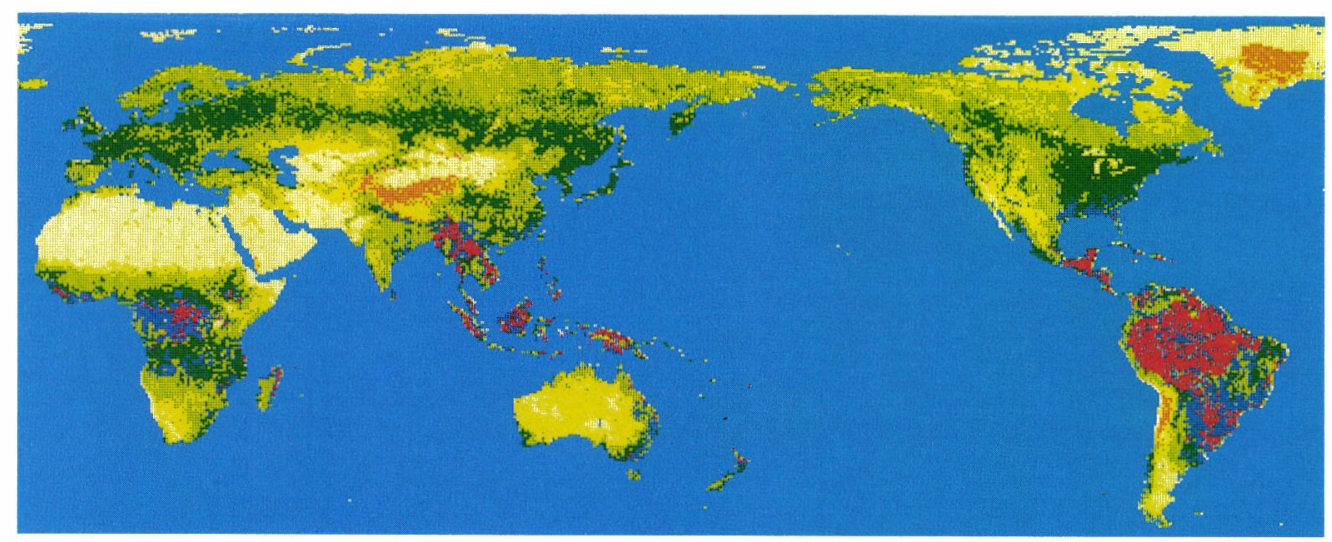

図 $3-4$ 1986年 世界植生図

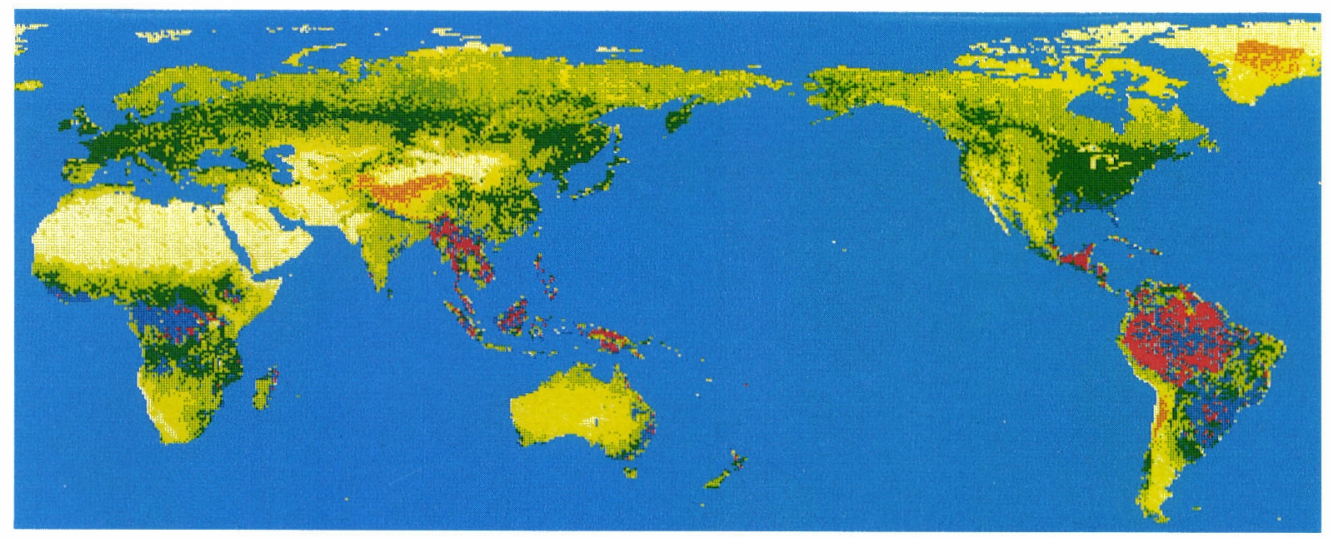

図 3 - 5 1987年 世界植生図
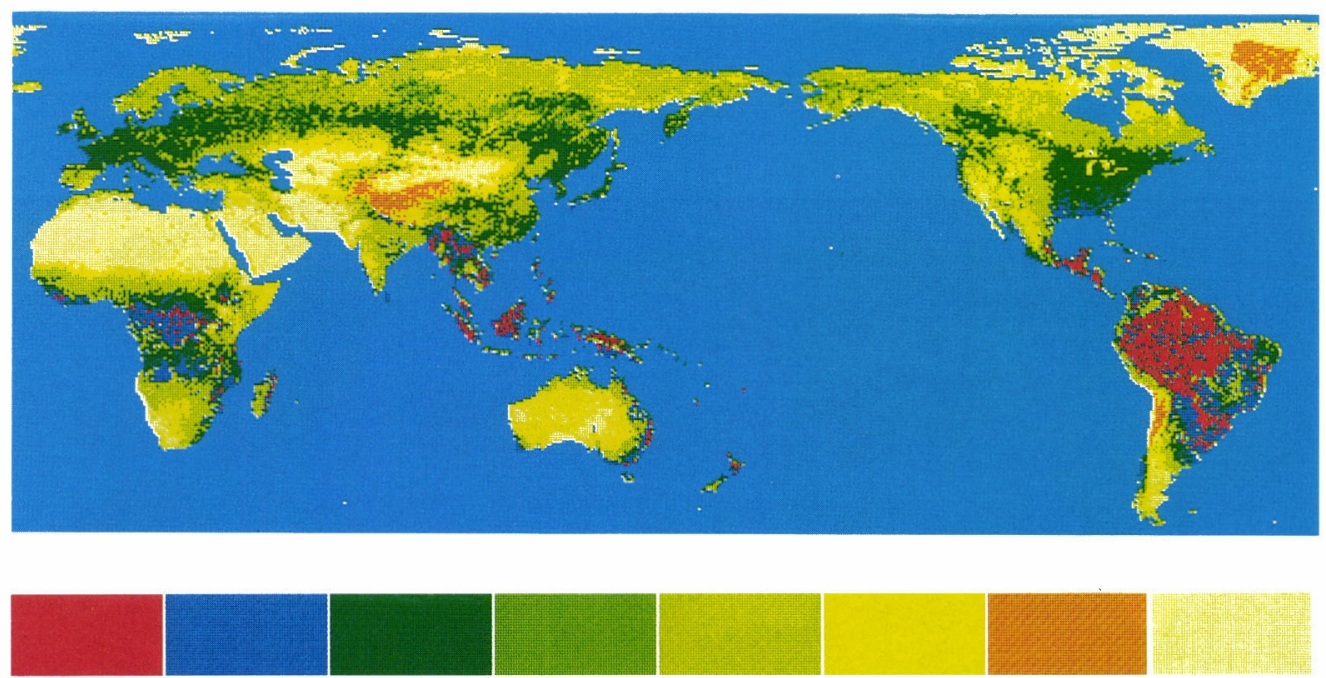

熱帯林

常緑樹林

ツンドラ

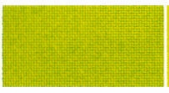

落葉樹林

草 原

半砂漠

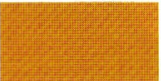

図 3-6 世界植生図 1985年から1987年の平均値

高山性

砂 漠 